\title{
Segmenting Investors on their Biases Manifested in Investment Decision-Making by Individual Investors
}

\author{
Afreen Fatima $\mathbb{D}^{*}$, Jitendra Kumar Sharma ${ }^{2}$ \\ 1,2Department of Business Administration, University of Lucknow, India \\ * Corresponding author: ansariaf786@gmail.com
}

\begin{abstract}
Article History
Received 2021-06-05

Revised 2021-07-09

Accepted 2021-07-10

Published 2021-07-11
\end{abstract}

\section{Keywords}

Investment decision-making,

Psychological biases,

Segmentation,

Individual investors,

Factor analysis

\section{How to cite?}

Fatima, A., \& Sharma, J. K. (2021).

Segmenting Investors on their Biases

Manifested in Investment Decision-Making

by Individual Investors. SEISENSE

Journal of Management, 4(4).

doi:10.33215/sjom.v4i4.663

Copyright (C) 2021 The Author(s)

(cc) BY
Purpose- This study proposes to identify the certain biases affecting investor decision-making and to segment investors accordingly.

Design/Methodology- A quantitative research method was applied to measure the existence and impact of the biases on investment decision-making. A survey was administered among the stock market investors in Uttar Pradesh. Factor analysis was used to extract those biases that significantly impact investment decisionmaking and their mean score to assess the level of agreement that affects their investment decisions.

Findings - The finding reveals that eight extracted factors affect the investment decisions and accordingly segment them on the biases they exhibit. The investors tend to fall into Imitator, Stereotypical, Independent Individualist, Risk Intolerant, Efficient Planner, Confident, Passive, and Competent Confirmer. The Imitators, Independent Individualists, and Confident investors show their higher level of agreement that highly affects their equity investment decision-making.

Practical Implication- This study provides a base to segment the investors on their biases. In addition, it will help in customizing the investment recommendation based on their biases to improve the investment decisions. 


\section{Introduction}

India has come forth as an attractive investment courtyard after economic reforms. It has a large consumer base representing 7.2\% GDP growth in 2017-18 (Economic Survey, 2018-19). Edelweiss (2010) has stated in his report that India has the highest household saving rate compared to other countries in the world. The most populous state of India, Uttar Pradesh, has achieved the third position with an $8.13 \%$ share of total GDP at current prices of India among other Indian states during 2016-17(Statistics Times, 2019). Hence, it expands the income levels of household and domestic consumption that stabilize the country's economic growth. However, the financial market offers a variety of opportunities for investment and saving products with overloaded information. Generally, individuals are exposed to investment avenues driven by their beliefs and preferences due to inadequate knowledge and expertise. This situation leads to the deviation from rational decisions, and individuals expose to several biases. The onset of behavioral finance has proved the irrationality in the light of behavioral and psychological factors (Koutidis et al., 2011; Clark-Murphy and Soutar, 2004; Koutidis et al., 2011; Sahi, 2012; Fatima \& Sharma, 2019).

The field of psychology is significant to comprehend individual investors better by explaining the irrational decisions in the stock market. Analyzing the investors' psychological state and overcoming their influences are the only means to achieve good returns in the stock market. Investor's decisions are also affected by differences in their socio-demographic structure. Technological advancement has brought a significant shift in India's investor's attitudes and preferences (Sahi, 2012). This shift creates obstacles for market players to cater to the investor's needs and preferences. Gupta (1991) has stated that financial analysts need a good understanding of the investors' behavior in managing the investment portfolio of investors. The emergence of behavioral finance has become the explanation of irrational behavior and suggested that individual investors have usually influenced by a combination of psychological factors (Jain et al., 2015; Fatima \& Farhat, 2019). Behavioral finance literature identifies that several psychological biases are accountable for making irrational decisions (Chandra and Kumar, 2011; Fatima et al., 2018; Raut et al., 2018; Fatima, 2018). Hence, it is observed that several biases affect investment decisions. Therefore, it is worth investigating to segment inventors based on their psychological biases, which give insights about group-specific biases in investment decision-making. This study contributes to the theoretical literature of behavioral finance related to investors' segmentation and demonstrates the influence of different psychological biases on their investment decision-making.

In this study, we propose to study the investment decision-making of individual equity investors with the stated following objectives:

1. To segment the investors based on the distinct biases they exhibit.

2. To determine the level of agreement of respondents on the factor obtained that affect their investment decision-making.

\section{Motivation of the Study}

Behavioral finance helps to understand why individuals make a particular investment decision while facing stock market anomalies. The thoughts and behavior of individual investors affect their investing and trading activities as well. The stock market represents the collective actions of the need to explore the psychological biases influencing investment decision-making in the Indian equity market. Individual and institutional investors whose psychological biases may have more or less assertive based on their experiences. Therefore, the purpose of segmenting the equity investors is to customize their investment portfolio. The findings of this study will help in identifying the different types of biases that an investor generally tend to have, which gives an idea to understand their irrational investment decisions. Hence, it provides the basis to understand what types of distinct biases exist among equity investors. 


\section{Literature Review}

Investors' decision-making patterns have been a branch of interest for portfolio managers, brokers, and academic researchers. Investors consider purchasing only the most desirable stocks along with having many preferences of the stores. Odean (1999) has exerted that the selling decisions of investors have mainly based on their level of interest and awareness about the past performance of the stocks. The investment decisions are always anteceded by prediction and perception of the individuals that impact the emotional and psychological decisions on the stock market (Sadi et al., 2011). Usually, those investors who face the time shortage and lack of expertise often prefer to choose a heuristic strategy to process the information for decision-making (Ackert et al., 2010). The current study considers seven biases, namely, heuristics theory factors, i.e., overconfidence, representativeness, availability, herding, and others factor, i.e., information cascading, social influence, and risktolerance, that frequently observed in the Indian stock market. The literature supports the fact that psychological biases affect investment decision-making in the Indian context.

\section{Heuristics}

Heuristics are a rule of thumb used by investors to make decisions more easily and quickly in uncertain and complicated situations (Ritter, 2003). It reduces the complicacy of evaluating probabilities and predicting values to simpler decisions (Kahneman \& Tversky, 1974). The use of heuristics sometimes leads to several biases in decision-making (Kahneman \& Tversky, 1974; Ritter, 2003). This paper uses heuristics in order analyze the factors affecting the investment decision-making, namely, representativeness and availability biases (Kahneman \& Tversky, 1974) and overconfidence (Waweru et al., 2008) and other biases such as herding (Waweru et al., 2008), information cascading (Raut et al., 2018), social influence (Fatima et al., 2018), risk- tolerance (Grable \& Joo, 2004).

\section{Representativeness}

Representativeness is an over-reliance on the stereotypes, and it helps develop misattribute about the stock and the past performance of a company (Shefrin \& Stateman, 1985). The investors might invest based on recent past returns of the company in the expectation to earn a good return (De Bondt, 1993). Previous studies have shown its impact on the investors' decisions in the Indian stock market (Raut et al., 2018; Dangi \& Kohli, 2018). Therefore, this study has included the impact of such stereotypical representativeness factor in the investment decision-making of Indian investors.

\section{Availability}

Availability bias occurs when an investor depends on readily available information excessively. It is an individual tendency to analyze the likelihood of an event because of the easiness of recalling similar instances. Several works of the literature suggest that the investors' decisions have affected the presence of this availability factor (Onsomu; 2014; Sukheja, 2016; Alrabadi et al., 2018).

\section{Overconfidence}

Another factor that influences investment decision-making is overconfidence, which tends to overestimate the accuracy of the available information and their capability to make decisions (DeBondt and Thaler, 1995; Rehan and Umer, 2017).Quaicoe and Eleke-Aboagye (2021) have found that overconfidence strongly influences the investor's decisions. The overconfident investors prefer to buy more stock in the bullish period under the overconfidence that leads to inefficiency in the market regarding mispricing and volatility (Shah et al., 2013).

\section{Herding}

It has been pointed out that most investors imitate their peers' behavior in the expectation of returns by overlooking their knowledge and expertise that influence the investment decisions (Gunay and Demirel, 2011; Rehan and Umer, 2017). Herding can be considered one of the responsible factors in determining the decision- 
making of Indian investors because societal expectations and peer pressure shape the individuals' decisions (Raut and Das, 2015; Raut et al., 2018; Dangi \& Kohli, 2018).Quaicoe and Eleke-Aboagye (2021) have reported that herding was the most dominant bias that influences investment decisions.

\section{Information Cascading}

Along with herd behavior, information cascades are also witnessed in the stock market, where investors have paid no attention to their private information while following the others for making decisions (Raut and Das, 2015; Raut et al., 2018). Huber, Klucharev, \& Rieskamp (2014) have stated that information cascades are somewhat rational herding which axioms that others' decisions influence the subsequent decision-makers to follow others by rationally disregarding their private information.

\section{Social-Influence}

Banerjee (1992) has observed that the individuals who have a common interest share and enjoy the stock market conversations. They usually prefer those decisions which their friends and colleagues make. Singh (2021) has evidenced that the opinion of stockbrokers, companies, friends, relatives and experienced investors is an essential factor influencing the investment decision of Indian investors. Investor's decisions are also influenced by the social interaction with family members and relatives that have prominently cited in various researches of behavioral finance (Fatima et al., 2018; Shanmugham \& Ramya, 2012).

\section{Risk-Tolerance}

Risk tolerance is the uncertainty of returns that individuals are willing to accept while making any financial decision (Grable, 2000). Graham et al. (2009) have argued that investors can undertake high risk with a high level of knowledge and skills. This paper focuses that risk tolerance is also accountable for determining investment decisions in individual investors.

\section{Investor Segmentation Researches}

The segmentation studies aim to understand the different strategies that individual investors can use for decision-making. Scant researches have been carried out to segment the investor based on their personality, demographics, risk-taking abilities, investment choice criteria, investment attitude and behavior, other psychological biases (Mittal and Vyas, 2008; Bailard et al., 1986; Barnewall, 1987; Lampenius and Zickar, 2005; Kasilingam and Jayabal, 2010; Warren et al., 1990; Nagpal and Bodla, 2009; Keller and Siegrist, 2006; ClarkMurphy and Soutar, 2005; Sahi and Arora, 2012; Paluri and Mehra, 2016; Kumar et al., 2018).The aforementioned psychological biases have been prominently apparent in the decision-making among irrational individual investors.

\section{Research Gap}

The stock market investors suffer losses by taking incautious and deceptive decisions. It becomes imperative to highlight the shreds of irrational behavior evidence using shortcuts in making decisions. Several studies have been conducted to analyze the irrational behavior of individual investors across the world. Only a few of them have been conducted from an Indian perspective to prove the existence of such anomalies and their impact on the decision-making of Indian investors. Besides, studies based on the segmentation of equity investors have been done very few in developing countries, i.e., India. Understanding the investor's biases category will assist the individuals in identifying their shortcomings while making decisions. This study attempts to bridge the gap in investor segmentation on their distinct biases in investment decision-making in the Indian context.

\section{Methodology}

This research is descriptive and cross-sectional data were used. This study's population and sampling unit were individual investors of the National Stock Exchange and an individual investing in equity stocks, respectively. 
The thumb rule is sample size should be five times more than the number of statements under factor analysis (Kass \& Tinsley, 1979). This study used a greater sample size than the thumb rule. The 400 questionnaires were distributed to the equity investors of Lucknow, Kanpur cities of Uttar Pradesh, out of which 345 questionnaires were returned. Firstly, the collected data were cleaned by discarding the questionnaire with low quality, such as 40 uneven responses and 41 incomplete responses. The triangulation method was applied to collect data from multiple sources to enhance the construct validity in an online and offline questionnaire. The samples of 264 answers were in a complete form, accounting for the response rate of $66 \%$, a moderately high rate for a postal questionnaire survey (Luu, 2010). The processed data were analyzed by IBM SPSS 20.0 software to use the statistical techniques include Descriptive Statistics and Factor Analysis.

\section{Questionnaire Design and Construct Measurements}

The purpose of the questionnaire is to provide a basic understanding of the factors that affect investment decision-making. The questionnaires were sent to respondents using snowball sampling to get a quick response by sending through friends, colleagues, and students. The whole questionnaire was divided into two parts: personal information and psychological factors affecting the decision-making. The questionnaire has included some demographic variables and seven biases having 32 items were assessed. The preferable five-point Likert scale was used for asking the degree of their agreement with the statements of psychological factors on their investment decision-making, where 5 denotes the strongly agree, and 1 denotes the strongly disagree.

The pilot study has been conducted to ensure the reliability of the construct, calculated Cronbach's alpha for the Likert items with a 50 sample of investors, then finalized and utilized for the survey. A coefficient value greater than or equal to 0.6 is recognized as a standard alpha value that shows a good construct reliability sign (Cronbach, 1951). In perceptual studies, the value of Cronbach's alpha 0.5 is also acceptable, as advocated by Nunnally (1976). The alpha values of all the constructs lie between .563 to .789 that shows each construct is valid and reliable for the survey instrument. It represents the scales used in the survey instrument is carrying the objective of uni-dimensionality.

\section{Data Analysis and Results}

\section{Demographic Profile of the Respondents}

Table 1 - Descriptive Statistics of the Sample

\begin{tabular}{llll}
\hline Distribution of the Sample & & & \\
\hline Variables & Categories & Frequency & Percentage \\
Gender & Male & 194 & 73.5 \\
& Female & 70 & 26.5 \\
Age & Below 25 Years & 17 & 6.4 \\
& 25-35 Years & 22 & 8.3 \\
& 36-45 Years & 87 & 32.9 \\
& $46-55$ Years & 104 & 39.4 \\
Marital Status & Above 55 & 34 & 12.9 \\
\multirow{2}{*}{ Education } & Married & 221 & 83.7 \\
& Unmarried & 43 & 16.3 \\
& Graduate & 69 & 26.1 \\
& Master & 108 & 40.9 \\
\hline
\end{tabular}




\begin{tabular}{llll}
\hline Occupation & Students & 24 & \\
& Salaried & 39 & 14.8 \\
& Business & 107 & 40.5 \\
& Professional & 76 & 28.8 \\
& Retired & 18 & 6.8 \\
Annual Income & Below 2.5 lacs & 23 & 8.7 \\
& 2.5-05 lacs & 54 & 20.5 \\
On-10 lacs & 115 & 43.6 \\
Investment Experience & Above 10 lacs & 72 & 27.3 \\
& 0-2 Year & 19 & 7.2 \\
& 2-4 Year & 49 & 18.6 \\
& 4-6 Year & 79 & 29.9 \\
& 6-8 Year & 93 & 35.2 \\
& Above 8 Year & 24 & 9.09 \\
\hline
\end{tabular}

Source: Author Compilation

The result of a demographic summary is reported in Table 1. The sample consisted of 194 male (73.5\%) and 70 female $(26.5 \%)$ investors, representing that males prefer stock market investment to females. The age distribution of the sample is categorized as below 25, 25-35, 36-45, and 46-55 and above. Age ranges between 46-55 and 36-45 were highly represented in the sample, 39.4\% \& 32.9\% of the sample, respectively. The least representative of the sample was $6.4 \%$ (Below 25). It shows that matured persons are more prone to take the risk in equity stocks. In terms of marital status, $83.7 \%$ of investors $(\mathrm{N}=221)$ were married, and $16.3 \%$ were unmarried $(\mathrm{N}=6)$, indicating that married investors are more inclined towards heuristics than unmarried ones.

The education levels of investors were grouped as a graduate, master, and advanced degree. The highest percentage of respondents holds master's and advanced degrees (40.9\% and 32.9\%), proving that respondents have enough knowledge about stock market investments. The occupation of the respondents categorizes as student, salaried, business, professional, and retired. Based on the investors' occupation, businessperson covers a large portion of the sample, i.e., $40.5 \%$ and $28.8 \%$ were professional in their occupation. The salaried investors constitute only a $14.8 \%$ portion of the sample. This implies that investors possess a good knowledge of equity investment that again points out the reliable responses from the majority of the respondents.

The annual income of the respondents is categorized into four groups. The highest number of respondents falls into the 05-10 lacs income bracket (43.6\%), followed by the annual income of respondents were $>10$ lacs indicates that investors having higher incomes are more prone to invest in risky stocks. On the ground of investor experience, most respondents have more than 4 years of investment experience and come under the ranges between 4-6 \& 6-8 years of experience (35.2 \& 29.9\% respectively). This indicates that investors have certain years of experience in dealing with equity stocks.

\section{Factor Analysis of the Psychological Factors affecting Investment Decision-Making}

The exploratory factor analysis (EFA) was used for the psychological factors to identify the new factors affecting the investor's decision-making. Kaiser-Meyer-Olkin (KMO) test of sampling adequacy and Bartlett's test of sphericity are used to determine the factorability of the matrix as a whole (George \& Mallery, 2003).

$\mathrm{KMO}$ analysis represents whether the data is adequate for conducting the Factor analysis. The results value of $\mathrm{KMO}$ is 0.758 , which is greater than 0.6,which depicts it is meritorious. Bartlett's test of sphericity measures the multivariate normality of data. The test result is significant (3099.800) or in error margin, i.e., $\mathrm{p}<0.000$ is presented in Table 2. If the significant value is less than 0.05 , that indicates that data does not produce an 
identity matrix. Thus, data is multivariate normal and suitable for conducting factor analysis (Coakes and Ong, 2011).

Table 2 - KMO and Bartlett's Test

Kaiser-Meyer-Olkin Measure of Sampling Adequacy

\section{Bartlett's Test of Sphericity}

$\begin{aligned} \text { Approx. Chi-Square } & 3099.800 \\ \text { Df } & 496 \\ \text { Sig. } & .000\end{aligned}$

\section{Inferential Statistics}

After ensuring the data was appropriate through KMO and Bartlett's sphericity test, we ran factor analysis. There are ten factors extracted using the principal component analysis under extraction method and the rotation method of Varimax with Kaiser Normalization criteria of Eigen value more than one (1.063). The ten factors explain a sizable percentage of total variance explained is $65.453 \%$, and all factors loadings are more than 0.5. The communalities values have more than 0.5 values, and all the diagonal values of the anti-image matrix have more than 0.6 values. Therefore, these indexes are advisable to run factor analysis that is fit and accepted for this study. The result of factor analysis is shown in total variance explained and rotated component matrix as depicted in Tables $3 \& 4$, respectively.

Table 3. Total V ariance Explained

\begin{tabular}{|c|c|c|c|c|c|c|c|c|c|}
\hline & \multicolumn{3}{|c|}{ Initial Eigen values } & \multicolumn{3}{|c|}{$\begin{array}{c}\text { Extraction Sums of Squared } \\
\text { Loadings }\end{array}$} & \multicolumn{3}{|c|}{$\begin{array}{c}\text { Rotation Sums of Squared } \\
\text { Loadings }\end{array}$} \\
\hline & Total & $\begin{array}{c}\% \text { of } \\
\text { Variance }\end{array}$ & $\begin{array}{c}\text { Cumulative } \\
\%\end{array}$ & Total & $\begin{array}{c}\% \text { of } \\
\text { Variance }\end{array}$ & $\begin{array}{c}\text { Cumulative } \\
\%\end{array}$ & Total & $\begin{array}{c}\% \text { of } \\
\text { Variance }\end{array}$ & $\begin{array}{c}\text { Cumulative } \\
\%\end{array}$ \\
\hline 1 & 6.78 & 21.21 & 21.21 & 6.78 & 21.21 & 21.21 & 3.23 & 10.09 & 10.09 \\
\hline 2 & 2.77 & 8.65 & 29.87 & 2.77 & 8.65 & 29.87 & 2.93 & 9.18 & 19.28 \\
\hline 3 & 2.08 & 6.49 & 36.37 & 2.08 & 6.49 & 36.37 & 2.68 & 8.40 & 27.68 \\
\hline 4 & 1.98 & 6.21 & 42.58 & 1.98 & 6.21 & 42.58 & 2.41 & 7.54 & 35.22 \\
\hline 5 & 1.42 & 4.45 & 47.04 & 1.42 & 4.45 & 47.04 & 1.90 & 5.96 & 41.19 \\
\hline 6 & 1.28 & 4.02 & 51.06 & 1.28 & 4.02 & 51.06 & 1.76 & 5.52 & 46.71 \\
\hline 7 & 1.23 & 3.86 & 54.93 & 1.23 & 3.86 & 54.93 & 1.69 & 5.30 & 52.02 \\
\hline 8 & 1.18 & 3.71 & 58.64 & 1.18 & 3.71 & 58.64 & 1.62 & 5.07 & 57.10 \\
\hline 9 & 1.11 & 3.49 & 62.13 & 1.11 & 3.49 & 62.13 & 1.46 & 4.56 & 61.66 \\
\hline 10 & 1.06 & 3.32 & 65.45 & 1.06 & 3.32 & 65.45 & 1.21 & 3.78 & 65.45 \\
\hline 11 & 0.93 & 2.93 & 68.38 & & & & & & \\
\hline 12 & 0.88 & 2.75 & 71.13 & & & & & & \\
\hline 13 & 0.84 & 2.63 & 73.77 & & & & & & \\
\hline 14 & 0.81 & 2.54 & 76.32 & & & & & & \\
\hline 15 & 0.78 & 2.44 & 78.76 & & & & & & \\
\hline 16 & 0.68 & 2.15 & 80.92 & & & & & & \\
\hline 17 & 0.64 & 2.01 & 82.93 & & & & & & \\
\hline 18 & 0.61 & 1.91 & 84.84 & & & & & & \\
\hline 19 & 0.54 & 1.68 & 86.53 & & & & & & \\
\hline 20 & 0.51 & 1.60 & 88.13 & & & & & & \\
\hline 21 & 0.48 & 1.50 & 89.64 & & & & & & \\
\hline 22 & 0.43 & 1.36 & 91.01 & & & & & & \\
\hline 23 & 0.41 & 1.30 & 92.31 & & & & & & \\
\hline 24 & 0.37 & 1.16 & 93.48 & & & & & & \\
\hline 25 & 0.35 & 1.11 & 94.59 & & & & & & \\
\hline
\end{tabular}




\begin{tabular}{lllr}
\hline 26 & 0.33 & 1.03 & 95.63 \\
27 & 0.30 & 0.93 & 96.57 \\
28 & 0.27 & 0.86 & 97.43 \\
29 & 0.25 & 0.80 & 98.23 \\
30 & 0.21 & 0.68 & 98.92 \\
31 & 0.19 & 0.59 & 99.52 \\
32 & 0.15 & 0.47 & 100.00 \\
\hline
\end{tabular}

Extraction Method: Principal Component Analysis

Table 4. Rotated Component Matrix ${ }^{a}$

\begin{tabular}{|c|c|c|c|c|c|c|c|c|c|c|}
\hline & \multicolumn{10}{|c|}{ Component } \\
\hline & 1 & 2 & 3 & 4 & 5 & 6 & 7 & 8 & 9 & 10 \\
\hline $\begin{array}{l}\text { Other investors' decisions of the stock } \\
\text { volume have an impact on your } \\
\text { investment decisions. }\end{array}$ & .785 & & & & & & & & & \\
\hline $\begin{array}{l}\text { Other investors' decisions of buying } \\
\text { and selling stocks have an impact on } \\
\text { your investment decisions. }\end{array}$ & .712 & & & & & & & & & \\
\hline $\begin{array}{l}\text { Other investors' decisions of choosing } \\
\text { stock types have an impact on your } \\
\text { investment decisions. }\end{array}$ & .680 & & & & & & & & & \\
\hline $\begin{array}{l}\text { You usually react quickly to the changes } \\
\text { of other investors' decisions and follow } \\
\text { their reactions to the stock market. }\end{array}$ & .636 & & & & & & & & & \\
\hline $\begin{array}{l}\text { I prefer to sell stocks on the days when } \\
\text { the value of the stock market index } \\
\text { decreases. }\end{array}$ & .580 & & & & & & & & & \\
\hline $\begin{array}{l}\text { I consider the information from my } \\
\text { close friends and relatives as a reliable } \\
\text { reference for my investment decisions. }\end{array}$ & .500 & & & & & & & & & \\
\hline $\begin{array}{l}\text { Before investing, I use trend analysis of } \\
\text { some representative shares to make } \\
\text { investment decisions for all stocks. }\end{array}$ & & .687 & & & & & & & & \\
\hline $\begin{array}{l}\text { I expect to invest in the stock market in } \\
\text { the near future (in the coming years). }\end{array}$ & & .683 & & & & & & & & \\
\hline $\begin{array}{l}\text { I often try to get information regarding } \\
\text { the evaluation of stock prices. }\end{array}$ & & .677 & & & & & & & & \\
\hline $\begin{array}{l}\text { I consider good stocks are related to } \\
\text { firms with past consistent earnings } \\
\text { growth. }\end{array}$ & & .590 & & & & & & & & \\
\hline $\begin{array}{l}\text { I expect my investments to perform } \\
\text { better than the stock market. }\end{array}$ & & .526 & & & & & & & & \\
\hline $\begin{array}{l}\text { I buy 'hot' shares, which provided a } \\
\text { return recently, and avoid shares that } \\
\text { have performed poorly in the recent } \\
\text { past. }\end{array}$ & & & .733 & & & & & & & \\
\hline $\begin{array}{l}\text { I avoid investments in shares that have } \\
\text { a history of poor earnings. }\end{array}$ & & & .708 & & & & & & & \\
\hline $\begin{array}{l}\text { I believe that the future value of shares } \\
\text { could be determined through a detailed }\end{array}$ & & & .688 & & & & & & & \\
\hline
\end{tabular}


analysis of past performance in the equity market.

I consider the past performance of the share before investing in it.

I am more comfortable putting my money in a bank account than in the stock market.

When I think of the word "risk", the term "loss" comes to mind immediately.

In terms of investing, safety is more important than returns.

Making money in stocks and bonds is based on luck.

I feel more confident in my own investment opinions over the opinions of financial analysts and advisors.

I feel more confident in my own investment opinions over the opinions of friends and colleagues.

I use my own information to make investment decisions.

I feel that on average, my investments perform better than the stock market.

When I purchase a winning investment, I feel that my actions and knowledge affected the result.

I am an experienced investor. I would prefer to invest in local stocks than international stocks because the information of local stocks is more available.

I prefer to buy local stocks than international trade-in ones.

I am likely to purchase investments that have been recommended by friends or colleagues.

I think people's information is important than the information I have.

I prefer to buy stocks on the days when the value of the stock market index increases.

Investing is too difficult to understand.

Extraction Method: Principal Component Analysis.

Rotation Method: Varimax with Kaiser Normalization.

a. Rotation converged in 14 iterations.

\section{Discussion on Investor's Segments}

Factor 1 incorporates six items and has variables related to herding and availability with the factor loading differences between .500 to.785. Since all these variables are indicated the behavior to follow the others, this factor can be labeled as 'Imitator Investors.' Imitator Investors are those who follow the herd in their 
investment decisions and consider the advice of close friends and relatives as a reliable source of information (Dangi \& Kohli, 2018). Thambireddy et al. (2021) have also confirmed the presence of herd behavior while making investment decisions.

Factor 2 incorporates five items and has variables related to representativeness, social influence, and overconfidence, with the factor loading differences between .526 to .687. Since all these variables are represented the detailed analysis of stock prices by the investors, this factor can be labeled as 'Stereotypical Investors.' Stereotypical investors invested only after exerted trend analysis of the stocks and believed they could thoroughly analyze the investment decisions. They are also responsible for using a case to represent their investment pattern (Dangi \& Kohli, 2018).

Factor 3 incorporates four items and has variables related to representativeness, with the factor loading ranging from .558 to .733 . Since this variable depicts that investors rely on the stock's past performance, this factor can be labeled as 'Independent Individualist.' These investors are not experienced and self-dependent, and they make investment decisions by the complete assessment of past performance and history of the stocks (Pompian, 2008).

Factor 4 incorporates four items and has variables related to risk tolerance, with the factor loading ranging from .543 to .717 . Since this variable depicts investors' risk-taking abilities, this factor can be labeled as 'Risk Intolerant Investors.' These investors are unwilling to take risks and trade less, and they prefer safety to high returns (Wood and Zaichkowsky, 2004).

Factor 5 incorporates three items and has variables related to overconfidence and information cascade, with the factor loading ranging from .547 to .791. Since these variables showed the self-confident nature of investors, this factor can be labeled as 'Efficient Planner Investors.' These investors tend to plan for investments and do not prefer to rely on financial advisors, friends, or colleagues. They have confidence in their information to make good investment decisions (Sahi \& Arora, 2012).

Factor 6 incorporates three items and has a variable related to overconfidence, with the factor loading ranges from .612 to .733. Since this variable explains investors' confidence level about their knowledge and expertise, this factor can be labeled as 'Confident Investors.' The confident investors consider themselves smart and experienced investors. They are more active and can take a higher risk (Wood and Zaichkowsky, 2004; Pompian, 2008). The result supports the finding of Thambireddy et al. (2021).

Factor 7 incorporates only two items and has a variable of availability with the factor loading ranging from .718 to .774. Since this variable shows the investors' familiarity with stocks, this factor can be labeled as 'Passive Investors.' These investors prefer to invest in local or domestic stock because of familiarity and information availability. They hesitate to trade in international stocks (Dangi \& Kohli, 2018).

Factor 8 also incorporates two items and has variables of information cascading and overconfidence, with the factor loading ranges from .590 to .752. Since these variables represent the nature of believing others' information, this factor can be labeled 'Competent Confirmer Investors.' These investors rely on others, i.e., friends, colleagues, spouses, and financial experts. They believe that investment performs well if it is guided by others (Sahi \& Arora, 2012).

\section{Cronbach's Alpha Test for New Factors:}

Cronbach's alpha is used to assess the internal consistency of eight extracted factors from the factor analysis. The result is presented in Table 5. The value of Cronbach's Alpha is ranging from 0.587 to 0.805 , which indicates that these factors are reliable and consistent for the use of further analysis (Cronbach, 1951; Nunnally, 1976). 
Table 5. Cronbach's Alpha Test

\begin{tabular}{cclc}
\hline Factors & No. of items & Factors Name & Cronbach's Alpha $(\alpha)$ \\
\hline $\mathbf{1}$ & 6 & Imitator Investors & .805 \\
$\mathbf{2}$ & 5 & Stereotypical Investors & .757 \\
$\mathbf{3}$ & 4 & Independent Individualist' Investors & .764 \\
$\mathbf{4}$ & 4 & Risk Intolerant Investors & .684 \\
$\mathbf{5}$ & 3 & Efficient Planner Investors & .629 \\
$\mathbf{6}$ & 3 & Confident Investors & .602 \\
$\mathbf{7}$ & 2 & Passive Investors & .614 \\
$\mathbf{8}$ & 2 & Competent Confirmer Investors & .587 \\
\hline
\end{tabular}

\section{Impact Levels of Extracted Factors on Individual Investment Decision-Making}

In Table 3, the total variance explained represents the highest variation. It gives only the weight of the factors in terms of percentage of all factors, while the mean score gives the respondents' level of agreement or disagreement for each factor obtained. Firstly, we transform the extracted factors into new factors because the extracted factors always in a standardized form that has zero mean and one standard deviation. To resolve the second objective of this study, the impact levels of extracted factors on the individual investment decisionmaking were identified by calculating each factor's mean score. Because 5-point scales were used to assess the levels of agreement of these variables, the mean values of these factors can help to decide the levels of agreement of respondents, which will affect their investment decision-making by the following rules:

- If the Mean values are less than 3, the respondents have a distinct level of disagreement on the variables of the factors (low impact).

- If the Mean values are between 3 to 4 , the respondents have a neutral response on the variables of the factors (moderate impact).

- If the Mean values are between 4 to 5, the respondents agree on the variables of the factors (high impact).

Table 6. Impacts of obtained Factors on Investment Decision-Making:

\begin{tabular}{llcc}
\hline & Factors Name & Mean Score & Std. Deviation \\
\hline Fact_new1 & Imitator Investors & 4.09 & .545 \\
Fact_new2 & Stereotypical Investors & 3.45 & .810 \\
Fact_new3 & Independent Individualist' Investors & 4.12 & .554 \\
Fact_new4 & Risk Intolerant Investors & 3.88 & .671 \\
Fact_new5 & Efficient Planner Investors & 3.91 & .660 \\
Fact_new6 & Confident Investors & 4.87 & .519 \\
Fact_new7 & Passive Investors & 3.45 & .810 \\
Fact_new8 & Competent Confirmer Investors & 3.98 & .654 \\
\hline
\end{tabular}

Source: Survey data

\section{High Impact on Decision Making:}

The first obtained factor, i.e., Imitator Investors, has explained the high variation $(10 \%)$ in the total variance explained as reported in Table 3 that represents the decisions of imitator investors are highly affected by the variables of herding and availability. While the mean score of Imitator Investors $(M=4.09)$ also indicates that the respondents were agreed on the items of these variables and have a high impact on their decision-making. This proves that Imitator investors follow herd behavior and somehow influenced by availability biases while making an equity investment. It supports the findings of past studies conducted in the presence of these biases 
and considers herding a most prominent factor in the Indian stock market (Gupta \& Ahmad, 2016; Raut et al., 2018; Raut \& Kumar, 2018).Herding shows a higher influence on the investors' decision-making and considers as a most dominant bias (Quaicoe and Eleke-Aboagye, 2021).

The third factor, i.e., Independent Individualist' investors (M=4.12), shows a higher level of agreement on the items of representativeness, indicating that it has a high impact on their investment decision-making compared to Imitator Investors. It explained $9.18 \%$ variation that is less than the variance explained by imitator investors based on total variance. This study's finding is similar to findings of other studies (Raut et al., 2018; Raut \& Kumar, 2018; Dangi \& Kohli, 2018). Raut \& Kumar (2018) have also stated that inexperienced and experienced investors have a similar perception of representativeness.

The sixth factor, Confident investors $(M=4.87)$, indicates the highest agreement level on the items of overconfidence which shows their high impact on the decision making of Indian equity investors. Mishra and Metilda (2015) claimed that experience investor and their education increases the chances of overconfident decisions. This finding is also alike to the previous result of studies conducted in the Indian capital market (Raut et al., 2018; Raut \& Kumar; 2018). They claim overconfidence is the second most essential factor among Indian investors. Quaicoe and Eleke-Aboagye (2021) have also evidenced a strong influence of overconfidence on investment decisions.

\section{Moderate Impact on Decision Making:}

The three factors have a moderate impact on investment decision-making as they have mean values between 3 to 4. All of them are nearer to four, indicating that equity investors have a moderate level of agreement on the combination of variables. The mean value of Competent Confirmer investors $(M=3.98)$ is highest from Efficient Planner investors $(M=3.91)$ followed by Risk Intolerant investors $(M=3.88)$. Along with that, they have shown low variance as compared to other factors. This result supports the previous studies conducted across the world (Kengatharan \& Kengatharan, 2014; Raut et al., 2018).

\section{Low Impact on Decision Making:}

The two factors, such as Stereotypical investors and Passive investors $(M=3.45)$, have the same mean score. This signifies that these investors have a lower level of agreement on the items or combination of different variables that indicates that it has a low impact on the decision-making of individual investors. Singh (2021) also claims that the investment decisions of Indian investors are based on opinion-based factors, which include the opinions of stockbrokers, experts, companies, friends or relatives, and experienced individual investors. This finding is contrary to the results of Shanmugham \& Ramya (2012), which suggests that investment decisions are highly affected by social interaction as they get more information about stock investment.

\section{Conclusion}

Indian economy emerges as the most progressive economies in the world; it becomes imperative to understand the behavior of investors for financial service providers to develop confidence and trust of the individual investors by tapping their mindset, beliefs, and preferences. The psychological segments are one of the ways to cater to the needs of the individual investors by the financial service providers. This study investigated the factors affecting the investment decision-making of the investors that make a theoretical contribution to the literature of investor segmentation based on certain biases and to the field of behavioral finance.

This study used distinct factors or biases that affected investors' decision-making and segmented them into their biases. This study has resulted that most of the investors have a combination of biases that affect their decision-making - segmenting the individual investors from the obtained factors based on their biases that yielded eight investors segments, namely imitators, stereotypical, independent individualists, risk-intolerants, 
efficient planners, confidence, competent confirmers, and passive investors. These investors behave differently based on biases accordingly. The finding also reveals that the categories of imitators, independent individualists, and confident investors show a higher level of agreement on their respective biases. This indicates that herding, representativeness, and overconfidence biases are the most crucial for Indian equity investors that highly affect their decision-making. In the result of factor analysis, only the imitator investor's category explains higher variation. Still, the mean score of independent individualist and confident investors also represents their high impact on investment decision-making. These findings support the results of previous studies in the Indian context (Garg \& Gulati, 2014; Dangi \& Kohli, 2018; Raut \& Kumar, 2018).

The study has concluded by achieving all the objectives of this study, which were raised in the introduction. The recommendations for the individual investors are that they should take circumspectly before making any investment decisions and should not be concerned too much about the prior loss. This implies that it cannot consider that biases are errors in decision-making that require to be corrected if they do make investors satisfied with their investment planning and management.

\section{Research Implications}

This study provides some theoretical and practical implications for researchers and financial analysts/ policymakers. Segmentation studies are beneficial for financial planning, and advisors or fund managers can identify and try to evade repeating some behavioral mistakes. The study aimed to assess the impact of psychological biases on the investor's decision-making. This paper becomes distinguished itself by segmenting the equity investors of selected psychological biases in the decision-making. This study will give insights into the awareness of biases susceptible to their investment decisions and recommend taking care of these biases while making investments. The policymakers or fund managers should offer customized advice to their different profiles of investors and customized products \& services as per their biases highlighted in the findings of this study. They should consider an adoptive mixed investment strategy in the complex stock market to achieve higher returns in a volatile market where the investors' emotions play a vigorous role.

\section{Limitations and Future Scope for Research}

The segments of investor biases can guide the investors that enable them to better understand their preferences in decision making, which helps them make the planned investment choices. The limitation part is concerned; the study has a small sample size, and investors were approached in certain districts of Uttar Pradesh because the survey was administered only if investors were agreed. This would cause some impact on the findings of the study as the investors show a higher degree of conservatism in their investment beliefs while conducting the survey.

Future studies are accompanied to integrate neuroeconomics to know how decisions are made and how they can be improved. It would help to make the decisions more truthful and accurate across the boundaries of rationality. A longitudinal study would help check these factors or biases affecting investors' decision would remain stable or replace with other factors over the period to enhance the generalisability of the result.

Funding: This research received no external funding.

Acknowledgments: I acknowledge the Department of Business and Management, University of Lucknow, for their permission and support to conduct the research.

Conflicts of Interest: The authors declare no conflict of interest.

\section{References}


Ackert, L. F., Church, B. K., \& Tkac, P. A. (2010). An experimental examination of heuristic-based decision making in a financial setting. Journal of Behavioral Finance, 11(3), 135-149.

Ahmad, F. (2020). Personality traits as predictor of cognitive biases: Moderating role of risk-attitude. Qualitative Research in Financial Markets, 12(4), 465-484. https://doi.org/10.1108/QRFM-10-2019-0123

Alrabadi, D. W. H., Al-Abdallah, S. Y., \& Aljarayesh, N. I. A. (2018). Behavioral biases and investment performance: Does gender matter? Evidence from Amman stock exchange. Jordan Journal of Economic Sciences, 5(1).

Bailard, T.E., Biehl, D.L. and Kaiser, R.W. (1986). Personal money management (5th ed.) Science Research Associates, Chicago, IL.

Barberis, N.; Thaler, R. (2003). A survey of behavioral finance. Handbook of the Economics of Finance, 1, 1053-1128.

Barnewall, M.M. (1987). Psychological characteristics of the individual investor, inDroms,W. (Ed.), Asset Allocation for the Individual Investor, The Institute of Chartered Financial Analysts, Charlottesville, VA.

Banerjee, A. (1992). A simple model of herd behavior. The Quarterly Journal of Economics, 107(3), 797-817.

Chandra, A., \& Kumar, R. (2011). Determinants of individual investor behavior: An orthogonal linear transformation approach (Working Paper No. 29722). New Delhi: MPRA.

Clark-Murphy, M. and Soutar, G. (2005). Individual investor preferences: A segmentation analysis. The Journal of Behavioral Finance, 6(1), 6-14.

Clark-Murphy, M. and G.N. Soutar. (2004). What individual investors value: Some Australian evidence. Journal of Economic Psychology, 25(4), 534-555.

Cronbach, L.J. (1951). Coefficient alpha and the internal structure of tests. Psychometrika, 6(3), 297-334.

Dangi, M., \& Kohli,B. (2018). Role of behavioral biases in investment decisions: A factor analysis. Indian Journal of Finance, 12(3), 43-57.

DeBondt, W. F. M., \& Thaler, R. H. (1995). Financial decision-making in markets and firms: A behavioral perspective. Handbooks in Operations Research and Management Science, 9(13), 385-410. http://dx.doi.org/10.1016/S0927-0507(05)80057-X

De Bondt, W. P. (1993). Betting on trends: Intuitive forecasts of financial risk and return. International Journal of Forecasting, 9(3), 355-371.

Economic Survey (2018-19). Retrieved from https://www.ibef.org/economy/economic-survey-2018-19(2019, June, 12)

Edelweiss (2010). Edelweiss India 2020, Seeing Beyond.

Fatima, A. (2018). Behavioural finance: A need for understanding Indian investors behaviour. HermeneuticS: A Biannual Refereed International Journal of Business and Social Studies, 8(2), 286-290.

Fatima Akhtar, K.S. Thyagaraj, Niladri Das, (2018). The impact of social influence on the relationship between personality traits and perceived investment performance of individual investors: Evidence from Indian stock market. International Journal of Managerial Finance, 14(1), 130-148. https://doi.org/10.1108/IJMF-05-2016-0102

Fatima, A. \& Farhat, R. (2019). A study on the impediments of investors rationale. Global Journal of Engineering Science and Researches: Proceeding of an international conference held in Ambalika Institute, 22-23 February 2019, (COTII 2019, pp.7-15).

Fatima, A. \& Sharma, J. K. (2019). Review of biases in individual investment decision-making. Research Review International Journal of Multidisciplinary, 4(3), 1-7.

Garg, A., \& Gulati, R. (2014). Do investors herd in Indian market? Decision, 40(3), 181-196.

George, D., \& Mallery, P. (2003). SPSS for windows step by step: A simple guide and reference. 11.0 update (4th ed.) Boston: Allyn \& Bacon. 
Grable, J.E. (2000). Financial risk tolerance and additional factors that affect risk taking in every day money matters. Journal of Business and Psychology, 14(4), 625-630.

Grable, J. E., \& Joo, S. H. (2004). Environmental and biophysical factors associated with financial risk tolerance. Journal of Financial Counseling and Planning, 15(1).

Graham, J., C. Harvey, and H. Huang. (2009). Investor competence, trading frequency, and home bias. Management Science, 55(7), 1094-1106.

Gunay, S. G., \& Demirel, E. (2011). Interaction between demographic and financial behavior factors in terms of investment decision making. International Research Journal of Finance and Economics, 66, 147-156.

Gupta, Y., \& Ahmed, S. (2016). The impact of psychological factors on investment decision making of investors: An empirical analysis. EPRA International Journal of Economic and Business Review, 4(1).

Gupta, R. (1991). Portfolio management: The process and its dynamics. Working Paper No. 923, March, Indian Institute of Management, Ahmedabad.

Huber, R. E., Klucharev, V., \& Rieskamp, J. (2014). Neural correlates of informational cascades: Brain mechanisms of social influence on belief updating. Social Cognitive and Affective Neuroscience, 10(4), 589-597.

Jain R, Jain P and Jain C. (2015). Behavioral biases in the decision making of individual investors. IUP J Manage Res, 14, 7-27.

Jayaraj (2013). The factor model for determining the individual investment behavior in India. Journal of economics and finance, 1(4), 21-32.

J. C. Coakes and C. Ong, (2011). SPSS version 18.0 for windows analysis without anguish. (1st ed.) Dougall Street, Milton: John Wiley \& Sons Australia, Ltd.

Kahneman, D.; Tversky, A. (1974). Subjective probability: A judgment of representativeness. The Concept of Probability in Psychological Experiments, Springer Netherlands, 25-48.

Kass, R. A., \& Tinsley, H. E. A. (1979). Factor analysis. Journal ofLeisure Research, 11, 120-138.

Kasilingam, R. and Jayabal, G. (2010). Segmentation of investors based on choice criteria. ICFAI Journal of Behavioural Finance, 7(1/2), 76-91.

Keller, C., and M. Siergist. (2006). Investing in stocks: The influence of financial risk attitude and values-related money and stock market attitudes. Journal ofEconomic Psychology, 27(2), 285-303.

Kengatharan, L. and Kengatharan, N. (2014). The influence of behavioral factors in making investment decisions and performance: Study on investors of Colombo stock exchange, Sri Lanka. Asian Journal of Finance \& Accounting, 6(1), 1. Retrieved from https://doi.org/ 10.5296/ajfa.v6i1.4893

Kourtidis, D., Sevic, Z. and Chatzoglou, P. (2011). Investors' trading activity: A behavioural perspective and empirical results. The Journal of Socio-Economics, 40(5), 548-557.

Kumar, S., Goyal,N., Basu, R. (2018). Profiling emerging market investors: A segmentation approach. International Journal of Bank Marketing, 36(3), 441-455. https://doi.org/10.1108/IJBM-03-2017-0058

Lampenius, N. and Zickar, M.J. (2005). Development and validation of a model and measure of financial risktaking. The Journal of Behavioral Finance, 6(3), 129-43.

Luu, T. T. (2010). Organisational culture, leadership and performance measurement integratedness. International Journal of Management and Enterprise Development, 9(3), 251-275.Retrieved fromhttp://dx.doi.org/10.1504/IJMED.2010.037066

Mishra, K. C., \& Metilda, M. J. (2015). A study on the impact of investment experience, gender, and level of education on overconfidence and self-attribution bias. IIMB Management Review, 27(4), 228-239.

Mittal, M. and Vyas, R.K. (2008). personality type and investment choice - An empirical study. ICFAI Journal of Behavioural Finance, 5(3), 6-22.

Nagpal, S. and Bodla, B.S. (2009). Impact of investors' lifestyle on their investment pattern: an empirical study. Journal of Behavioral Finance, 6(2), 28-51. 
Ngoc, L. T. B. (2013). Behavior pattern of individual investors in stock market. International Journal of Business and Management, 9(1), 1-16.

Nunnally, C. J. (1978). Psychometric theory, McGraw Hill, New York.

Odean, T. (1999). Do investors trade too much? American Economic Review, 89(1), 1279-1298.

Onsomu, Z. (2014). the impact of behavioral biases on investor decisions in kenya: Male vs. female. International Journal of Research in Humanities, Arts and Literature, 2(6), 87-92.

Paluri, R. A. and Mehra, S. (2016). Financial attitude based segmentation of women in India: An exploratory study. International Journal of Bank Marketing, 34(5), 670-689.

Pompian, M. (2006). Behavioral finance and wealth management. Wiley Finance, 66-67.

Quaicoe, A. and Eleke-Aboagye, P.Q. (2021). Behavioral factors affecting investment decision-making in bank stocks on the Ghana stock exchange. Qualitative Research in Financial Markets, Vol. ahead-of-print No. ahead-of-print. https://doi.org/10.1108/QRFM-05-2020-0084

Rasheed, M. H., Rafique, A., Zahid, T., \& Akhtar, M. W. (2018). Factors influencing investor's decision making in Pakistan: Moderating the role of locus of control. Review of Behavioral Finance, 10(1), 70-87.

Raut, R. K., Das, N., \& Mishra, R. (2018). Behaviour of individual investors in stock market trading: Evidence from India. Global Business Review, 0972150918778915, 1-16.

Raut, R. K., \& Das, N. (2015). Behavioral prospects of individual investor decision making process: A review. Indian Journal of Finance, 9(4), 44-55. DOI:10.17010/ijf/2015/v9i4/71457

Raut, R. K., \& Kumar, R. (2018). Investment decision-making process between different groups of investors: A study of Indian stock market. Asia-Pacific Journal of Management Research and Innovation, 14(12), 39-49.

Rehan, R., \& Umer, I. (2017). Behavioural biases and investor decisions. Market Forces, 12(2), 12-20.

Ritter, J. R. (2003). Behavioral finance. Pacific-Basin Finance Journal, 11(4), 429-437.

Sadi, R., Asl, H., Rostami, M., Gholipour, A. and Gholipour, F. (2011). Behavioral finance: The explanation of investors' personality and perceptual biases effects on financial decisions. International Journal of Economics and Finance, 3(5), 234-241.

Sahi, S. (2012). Neuro-finance and investment behaviour. Studies in Economics and Finance, 29(4), $246-267$.

Singh, H. (2021). Review of factors influencing retail investors' investments decisions in the Indian stock market: An empirical study. Vivekananda Journal of Research, 10(1), 1-13

Shalini Kalra Sahi Ashok Pratap Arora, (2012). Individual investor biases: A segmentation analysis. Qualitative Research in Financial Markets, 4(1), 6-25.Retrieved from http://dx.doi.org/10.1108/17554171211213522

Shah, S. F. Raza, M. W., \& Khurshid, M. R. (2013). Overconfidence and perceived market efficiency. Interdisciplinary Journal of Contemporary Research in Business, 3(10), 1018-1026.

Shanmugham, R., \& Ramya, K. (2012). Impact of social factors on individual investors' trading behaviour. Procedia Economics and Finance, 2, 237-246.

Shefrin, H., \& Statman, M. (1985). The disposition to sell winners too early and ride losers too long: Theory and evidence. Journal of Finance, 40(3), 777-790.

Statistics Times (2019). Retrieved fromhttp://statisticstimes.com/economy/gdp-of-indian-states.php(2019, July, 12)

Sukheja, G.M. (2016). Behavioral biases in financial decision making. International Journal of Marketing, Financial Services and Management Research, 5(5), 60-69.

Thambireddy, H., Motiramani, J., Dharahasa, S., Anand, N. and Narahari, S. (2021). How psychological biases influence investors decisions - Evidence from Indian stock market. The Kiams Phronimos, 1(2), 1-14.

Warren, W.E., Stevens, R.E. and McConkey, C.W. (1990). Using demographic and lifestyle analysis to segment individual investors. Financial Analysts Journal, 46(2), 74-7. 
Waweru, N. M., Munyoki, E., \& Uliana, E. (2008). The effects of behavioral factors in investment decisionmaking: A survey of institutional investors operating at the Nairobi stock exchange. International Journal of Businessand Emerging Markets, 1(1), 24-41.

Wood, R., and J.L. Zaichkowsky. (2004). The institute of psychology and markets attitudes and trading behaviour of stock market investors: A segmentation approach. The Journal of Behavioural Finance, 5(3), 170-179. 